female heads of households and vulnerable women are illiterate with no income-generating skills, although they may be skilled as seamstresses, cooks, or midwives. Projects should be based on a participatory approach, and with sensitivity to the changing gender roles and relationships in the country of return. In order to ensure that women are included, a certain percentage of female beneficiaries should be written into all project documents and agreements.

\section{References}

Chantavanich E. and B. Reynolds, eds. 1988. Indochinese Refugees: Asylum and Resettlement. Bangkok: Chulalongkorn University.

Cooper, R. et al. 1991. The Hmong. Thailand: Artasia Press.

Forbes-Martin, S. 1992. Refugee Women. London: Zed Books.

Harrel-Bond, B.E. 1986. Imposing Aid. Oxford: Oxford University Press.

Kelly, N., ed. 1980. Working with Refugee Women-A Practical Guide. Geneva: NGO Working Group on Refugee Women.

Ledgerwood, J. 1992. Analysis of the Situation of Women in Cambodia. Phnom Penh: UNICEF.

Loescher, G. and L. Monahan. 1989. Refugees and International Relations. Oxford: Clarendon Press.

Shawcross, W. 1985. The Quality of Mercy. Bangkok: DD Books.

Standley, L. ed. 1990. Back to a Future? Bangkok: The Committee for the Coordination of Services to Displaced Persons in Thailand (CCSDPT).

Thorn, L. 1991. From Rice Truck to Paddy Field. Geneva: UNHCR.

UNHCR. 1990. Policy on Refugee Women. Geneva: UNHCR

- 1991. Guidelines on the Protection of Refugee Women. Geneva: UNHCR.

1992. Framework for People Oriented Planning. Geneva: UNHCR

Women's Commission for Refugee Women and Children. 1992. Going Home: The Prospect of Repatriation for Refugee Women and Children. Proceedings of Symposium by Women's Commission for Refugee Women and Children, June 8. Washington, D.C.

Zolberg, A.R. et al. 1989. Escape from Violence. Oxford: Oxford University Press. $\supset$

\title{
Elderly Mozambican Women Refugees in the Tongogara Refugee Camp in Zimbabwe: A Case Study
}

\author{
Dodo Thandiwe Motsisi
}

\section{Introduction}

In traditional African rural communities, the elderly often provide their wisdom, cultural orientation, and life experiences to the younger generation, and older women, in particular, frequently receive special recognition. However, the dislocation and the difficulties that some elderly persons experience in adjusting to alien social environments may lead to a lowering of their status in the community, when they can no longer perform their usual social responsibilities (Wiest, Mocellin, and Motsisi 1994, 32-33). Traditional extended family support may also disintegrate in refugee situations, as it has adverse effects on the mental and physical health of the elderly and their ability to cope (Popline 1991a, 3). Without sufficient understanding of the socioeconomic and cultural background of elderly refugee women (and, for example, their role as elders), Western planners may overlook their situation when planning assistance strategies.

This paper argues that development assistance interventions by international and domestic non-governmental organizations, as well as by the host governments assisting refugee women in the developing countries, need to be designed and planned from the vantage point of poor women (Sen and Grown 1985, 1). The perspective of poor women provides a unique and powerful vantage point for practical reasons. While development goals generally include improved standards

Dodo Thandiwe Motsisi is a Ph.D. candidate, and a member associated with the Disaster Research Unit, University of Manitoba. of living, elimination of poverty, access to dignified employment, and a reduction in social inequities, women are often deprived in one or more of these areas; they also make up the majority of the refugee camp population. Their concerns need to be heard.

Elderly rural women who have become refugees constitute a large group among the poor, the unemployed, and the economically disadvantaged in refugee camps. Some of the personnel interviewed for this study, who provide assistance in the refugee camps, have described these women as "having no energy," "a spent force," "with no real productive role," and have suggested that opportunities "need to be provided more for the younger women." Due to such attitudes, elderly women in refugee camps tend to be "pushed aside" (Munyai 1990) and their perspectives on issues are rarely solicited.

In general, women's work tends to be under-remunerated and undervalued, and the attitudes within refugee camps with respect to victims of mass displacement tend to reflect this view. At the same time, however, it is widely acknowledged that elderly women are vital to the continued survival of communities. Much of the labour of food production and processing, and the provision of fuel, water, health care, childrearing, sanitation, and other basic needs, are handled by elderly women in the refugee camps. Consequently, if we are to understand the impact of rural development and refugee assistance strategies upon the meeting of these basic needs, then the viewpoint of elderly women as producers and workers should be an obvious starting point. It has been noted that the vantage point of poor women 
enables us not only "to evaluate the extent to which development strategies benefit or harm the poorest and most oppressed sections of the people, but also to judge their impact on a range of sectors and activities crucial to socio-economic development and human welfare" (Sen and Grown 1985, 17).

I will argue that refugee assistance will improve the livelihood of elderly women only if it builds upon their cultural wisdom and life experiences. To accentuate this point, "learning from the poor" (Harrell-Bond 1986, 25-27, 259-61) should be a central point of departure for any refugee aid program. ${ }^{1}$ The research in this paper is based on information derived from policymakers in government (Camp Administrator's Office), the HelpAge Refugee Programme (Harare and Tongogara Office), as well as the United Nations High Commissioner for Refugees (UNHCR), who are key informants about the programs offered to elderly refugees in general, and women in particular. In addition, a semi-structured questionnaire was administered as an instrument to gather information among elderly Mozambican women at Tongogara camp in Zimbabwe in November and December 1992. Three researchers carried out the questionnaire survey. It was important to deploy Mozambican students because they understood not only the national culture, but also spoke the various languages used by the elderly women. Furthermore, they had a firm grasp of the geopolitical background of the Mozambican refugee question in Southern Africa. Also, observation and intense listening were additional forms of data gathering. Elderly women were encouraged to speak out about any issue they felt was important. Listening to their stories was a core aspect of the methodology used.

Using a stratified random sampling procedure, 140 households were selected in which elderly women were the key informants. They were selected from the HelpAge Office, which provided records from sixteen villages at
Tongogara camp in Zimbabwe. To be eligible, elderly women had to be at least fifty years old and receiving, or having previously received, assistance from HelpAge in the form of skills training. Finally, they had to consent freely to an interview, either in their homes (which was usually the case), or in a place convenient to them and the interviewer. The women interviewed ranged in age from 50 to 80 . The majority, 40.7 percent, were between 61 and 70 years old. Most of the widows were in this age group. The next group, 32.9 percent, were women between 51 and 60 years old, and 1.4 percent were over 71. Thirty-five percent did not know their exact age nor age bracket. The survey was intended to capture the social and economic background of these women before they left Mozambique and during their residence in the camp. It was thought that a comparison of their pre-flight and camp conditions would reveal whether or not they are better off in the camp, and would also illuminate the effectiveness of the assistance programs to which they are exposed.

\section{Household Relations}

The institution of polygamy is common in Africa, particularly in the rural areas, and Mozambique is no exception. For the elderly, polygamy has been an integral part of existence. It is inherently patriarchal, partly because it is essentially the man who has the option to have as many wives as he pleases. However, elders argue that polygamous marriages are one of the few remaining African institutions of family organization that "provide mutual support among families." This mutual support, they say, is the foundation of extended family relations. On the other hand, some women who were interviewed noted that polygamous marriages do not work for them "because my husband lives with a second wife and has neglected me." Feelings of abandonment often surface. They are also aware that due to polygamy, in the rural areas and particularly in the camps, girls as young as twelve are often forced into marrying much older men; discontent with this practice was often voiced in interviews. But elderly women in polygamous marriages also said that they tend to "survive better" (than women in non-polygamous marriages), "if the husband has a good heart." Men may enrol several times for food rations for their many wives and children, and are often able "to cheat the system" and acquire more for the family network.

Among the interviewed elderly women, 59.3 percent were widows, 38.6 percent were married, 1.4 percent were separated, and only 0.7 percent were single. Of those who were married, 27.9 percent were still living with their husbands in the camp. Some (4.3 percent) reported that their husbands were living with the second wife in Mozambique or elsewhere in the camp. Some ( 3.8 percent) mentioned that their husbands were working as migrant labourers in the South African mines and only visited them once a year around Christmas time. In a few cases, some women stated that their husbands were somewhere in Mozambique or had abandoned them.

Fifty-three percent of the women stated that they lived with three to six of their children. In some cases, due to extended family relations, some grandchildren are regarded by the women as their own children. Only 9.7 percent had none of their children living with them. Children and grandchildren provided a form of family support, particularly with regard to food and clothes rationing. Families with more children received more rations, but in any case the food rations were less than adequate (Keen 1992).

When asked about other relatives and their whereabouts, as well as whether or not they provided support for them, the majority of the interviewees (57.8 percent) indicated that they had relatives living elsewhere in the camp. Nine percent said their relatives lived elsewhere in Zimbabwe, either in another camp, or in the nearby town of Chipinge, or as far inland as Harare.

Other relatives have remained in Mozambique (6.4 percent) and a few (2.8 percent) have gone to work in 
South Africa. Whenever possible, the working relatives send cash or other items. The presence of other family members in other villages within Tongogara often meant that there was some emotional support for the elderly. In the camp situation, it was clear that:

Aid is applied in maintaining social institutions. Refugees are expected to cope by being appropriately "social," but they are denied the resources to re-establish the real bases of social life. ... In fact (some) aid workers often feel able to denigrate and devalue the "customs" which might help people to survive with more dignity (Harrell-Bond 1986, 292-93).

Sixteen percent of the refugees interviewed said they have no relatives in the camp or anywhere else. The figure may seem small but the effect is enormous. These women experience great loneliness, suffer from malnourishment more than other refugees, and often state that "we have no one to look after us."

For the most part, the HelpAge refugee workers are trained Social Workers, Project and Rehabilitation Officers, dedicated, equipped with analytic and problem-solving tools, and eager to help the elderly. However, the number of poor refugees is so large that the workers can help only a limited number (less than 50 percent of the elderly women and men in the Tongogara camp) (HelpAge 1992).

Ninety-three percent of the elderly women interviewed reported that they had no serious illness or disability; yet they often looked depressed and some were clearly destitute. Some of the women suffered from various forms of disability (2.1 percent were epileptic, 1.4 percent were partially deaf, another 1.4 percent partially blind, and the rest suffered from iodine deficiency and were thus susceptible to goitre and broken limbs; one had a club foot). They all stated, however, that their disability did not deter them from performing their duties, but that they needed to make an extra effort to survive in the camp environment.

\section{Level of Education and Skills Training}

In Mozambique, one of the colonial legacies of Portuguese rule was the denial of the right of black Mozambicans to an education (Hanlon 1984). The socialist regime of the late President Samora Machel promoted adult literacy programs, and the Organization of Mozambican Women (OMM) also played a significant role in establishing a viable educational system, but the sixteen-year war destroyed everything, including adult education programs. Among the elderly women interviewed (who had lived most of their lives under Portuguese rule), 95 percent had no formal education at all. Even the remaining five percent only had some primary school education.

HelpAge is the only agency offering diverse programs to the elderly women in the camp. The role of the elderly women in the selection of projects, and in planning, monitoring, and evaluation of these projects is, however, not clear.

HelpAge stated that needs assessment surveys had been carried out, but the elderly women interviewed said they were simply given opportunities to participate in projects but not design them. According to HelpAge records, all members of the identified group (elderly women, disabled women, and men) participated in the vegetable gardening project, which was meant to provide the elderly and the disabled with fresh green vegetables to supplement the monotonous and dry rations provided by the World Food Program (HelpAge 1992, 3).

One of the problems that arose from a rug-mat making project (besides lack of control and decision making concerning the type of payment in cash or in kind) seemed to be the lack of access to resources and control over production. Many elderly women interviewed by the research team said that they did not receive an adequate explanation regarding the financial resources needed to purchase sewing thread, needles, pieces of cloth, sack material, and the like. Some did not understand that producing a rug-mat is a complex procedure. They had invested an enormous amount of time and labour in creating the final product and they wondered why they only received one rug-mat after producing ten. This was particularly disturbing to them as they had no cash income.

The elderly women felt that they were not in control of the production process. They had the opportunity to participate in the project, which allowed them to acquire the skill entailed in producing rug-mats, but were not familiar with the costs of production, or the cost-benefit analysis that could have been provided to them in a simplified manner. As a result, the rugmat project did not empower them with access to and control over the entire production spectrum.

\section{Employment}

To plan refugee protection and assistance activities efficiently and effectively, refugee aid workers must analyze the social and economic roles of women and men in the refugee community and determine how these roles will affect and be affected by the planned activities (Anderson 1990, 7). In addition, the planned relief and skills training must correspond to the capacities of refugees, who are capable and willing to contribute actively to their own well-being in the camps when resources are available (Chambers 1979, Harrell-Bond 1986, Kibreab 1987, Hall 1988, Berar-Awad 1990 Brazeau 1990, Rogge 1990, Hanson 1992, Moussa 1992, Keen 1992, Bonga 1992, Refugee Studies Programme (Oxford) 1993). This is important with respect to the elderly and disabled in general, but particularly to the elderly women in the camps. They need to be given opportunities to regain control of their lives since their social roles of storytelling, caring for and nurturing the children, producing food by cultivating fields, and educating young girls who are entering womanhood, have been eroded by geographical and material displacement.

Slightly over one-half of the women interviewed said they were unem- 
ployed, while the rest described themselves as being "employed" by the HelpAge Refugee Program in the different skills-training projects offered by the agency. Ninety-six percent of the elderly women said they have received some form of skills training, in contrast to 3.6 percent who claimed to have received no training, in spite of appearing in the agency records as former or current trainees.

According to official government policy, camp refugees are not allowed to work (Zimbabwe Government 1983). HelpAge officers did not tell us that the elderly were "employed" by the HelpAge agency. The elderly women, however, reported that they understood themselves to be employed by the agency. They also reported that they were not involved in the decisions made regarding the type and amount of remuneration, but were happy to be given a chance to use their acquired skills, including knitting, gardening, making pottery and rugs, cutting hair, healing, sewing, and raising poultry. The elderly women informed us that "decisions on remuneration for our labour power are completely out of our control." Others reported that there is no standardized form of payment-in-kind. Hence the following comments: "I received a bar of blue soap a month, and whatever else when soap was not available;" "I never received any soap, but I did get a piece of cloth for a wrap-around;" "I received a jar of peanut butter." The elderly women report that this inconsistency of payment-in-kind created "confusion in our minds" and dissatisfaction.

\section{Repatriation}

Over 29 percent of the elderly women had been in Tongogara camp for less than one year. Since there was an intense drought at the time we conducted the survey, it is likely that these were refugees who fled to Zimbabwe because of the drought, rather than war-related reasons. Another 12.1 percent of the elderly women had been in the camp for less than two years, while 20 percent had been camp residents for six years or more. The remainder, 38.6 percent, had been in Tongogara for periods ranging between three and five years.

The cross-tabulation of results between "length of residence" and "desire to return" provided some interesting insights. First, it is clear that the longer the elderly women reside in the camp, the stronger their desire to go home. Second, more of the widows are in this category, particularly those who have been in the camps longer. When asked where they would prefer to resettle if safe repatriation took place in the near future, $\mathbf{9 7 . 2}$ percent responded that they would like "to go back to my own village." Only 1.4 percent of the total sample responded that they would prefer to "go to any safe area," and an equal number wished to "remain in Zimbabwe." Third, in spite of lengthy periods of residence (those who had been in the camp for six years and more), the attachment to home is still quite strong and hopes for a "return to Mozambique" are not forgotten. The three major reasons given by the women interviewed for wishing to return home reflect their strong attachment to their land: "it is my home" (65.7 percent), "my property is there" (33.6 percent), and "my ancestors are buried there" (17.9 percent).

In spite of a lengthy stay in the camps for some (their displacement was protracted by the sixteen-year conflict), the elderly women had not developed any roots in the camp, such that they would want to remain in the country. They did not particularly feel at home and, as many stated, "the younger people push us around." Although they complained of some camp staff, they nevertheless made it clear that they had excellent relations with the Camp Administrator, who always responded to their needs and problems as much as possible within the camp environment.

\section{Conclusion}

In summary, the most pressing problems in order of priority were: "desire to return," "inadequate clothing," "improper shelter," "insufficient food," "having no bucket," and "lack of salt."
Each of these expressed needs relates in one way or another to social relations in the household, in education, and in employment, as described in this paper. Relief assistance to the elderly women in refugee camps should address their needs regarding protection and emergency assistance for the short term (i.e. responding to the practical needs of the elderly women), as well as the rehabilitation and development of their capacities so as to prepare them for possible repatriation in Mozambique. During the latter phase, it is essential for elderly women to have access to and control over the resources that affect their lives.

Many agencies offering assistance to refugees, in spite of their good faith, still find it hard to believe that refugees know what is right for them. Thus they impose their aid through a variety of emergency assistance programs. ${ }^{2}$ When assisting rural refugees, it is essential to take note of both the positive and negative impacts such refugees have, particularly on even poorer hosts and communities in developing countries. ${ }^{3}$ In addition, refugees must be involved from the very beginning of project planning in the assessment of their own needs, and in translating needs-assessment findings into a project plan (World Council of Churches 1987, 1; Forbes Martin 1992).

If refugee participation in decision making and planning does not become central to the design of a project, or if refugees are involved only in the implementation phase, there is a greater risk that the situation will result in "increasing lethargy on the part of refugees, cost increases and a decrease in communication" (Cuny 1986). Cooperation of settlers is essential in order to make projects refugee-oriented and successful. ${ }^{4}$

Refugees should be empowered through these projects and not simply be regarded as passive participants. They must become agents of change who are in control of their situation. Some of the factors that need urgent consideration with respect to the elderly Mozambican refugee women of Tongogara are: 
- development of a clear understanding of the socioeconomic and cultural background of the women prior to their flight;

- relating skills-training activities to background information;

- ensuring that skills-training and income-generation projects correspond to the refugees' needs, and to the demands of the local host economy;

- relating skills-training activities to the demands of the local economy in Mozambique, in order to increase the degree of economic integration after repatriation;

- involving elderly women in the entire project cycle from the beginning (identifying, planning, implementing, monitoring, evaluating);

- increasing the elderly women's income-earning potential, thus fostering self-sufficiency;

- opening access to and promoting control over the production process (including making mistakes and learning from them) for the elderly women;

- alleviating the oppressive monotony of camp life; and

- providing a measure of self-respect that may have been lost through the years of unproductive exile (ATRCW 1986, 4).

\section{Notes}

1. An interview with HelpAge Refugee Programme in Zimbabwe former Director (Rhoda Immerman) and former Deputy Director (Meshack Mupinda) on October 8 1992, revealed an important factor about the agency's philosophy in assisting the elderly and disabled refugees in camps:

"One basic principle and approach that HelpAge has developed working with refugees is that, all projects need to be practical. For instance, we donotjust teach sewing, the refugees make women's pants because they would be needed as nobody supplies underwear ... So we are not just doing these things because people need to be occupied, we do that because it makes them do something good with their lives, but also helps their fellow people, and subsequently makes them feel good. It also boosts their self-esteem." (HelpAge)

2. Harrell-Bond (1986) emphasizes the right of refugees to decision making, to human rights, and to self-dignity in spite of the imposition of external aid.
3. An understanding of how refugees can affect poorer hosts in developing countries is essential in order that programs can benefit both refugees and local hosts in the villages surrounding the camps (Chambers 1986).

4. See Rogge (1987) for a discussion of several factors necessary to promote refugee selfsufficiency, including settler cooperation.

\section{References}

Anderson, M.B. and the UNHCR Senior Coordinator for Refugee Women. 1990. A Framework for People-oriented Planning in Refugee Situations. Geneva: UNHCR.

Berar-Awad, A. 1990. Statement to the Expert Group Meeting on Refugee and Displaced Women and Children, Vienna, 2-6. Geneva: International Labour Organization (ILO).

Bonga, V.M. 1992. "Refugees as a Development Resource: The Case of the Mozambican Refugees in Malawi." Paper prepared for the Conference on First Country of Asylum and Development Aid, 22. Malawi.

Brazeau, A. 1990. “Gender Sensitive Development Planning in the Refugee Context." Paper presented to the Expert Group on Refugee and Displaced Women and Children. Geneva: UNHCR.

Chambers, R. 1979. "Rural Refugees in Africa: What the Eye Does Not See." Disasters, 3, 4: 381-92.

-1986. "Hidden Losers? The Impact of Rural Refugees on Poorer Host." International Migration Review, Special Issue on Refugee Issues.

Cuny, F. 1986. Refugee Participation in Emergency Relief Operations. Washington, D.C.: Refugee Policy Group.

Forbes Martin, S. 1992. Refugee Women. London: Zed Books.

Hall, E. 1988. Vocational Training for Women Refugees in Africa: Guidelines from Selected Field Projects. Training and Discussion Papers. Discussion Paper No. 26. Geneva: ILO.

Hanlon, J. 1984. Mozambique: The Revolution Under Fire. London: Zed Books.

Hansen, A. 1992. Refugee Self-Settlement versus Settlement on Government Schemes: The Long-Term Consequences for Security, Integration and Economic Development of Angolan Refugees in Zambia (1966-1989). Geneva: United Nations Research Institute in Social Development.

Harrell-Bond, B.E. 1986. Imposing Aid: Emergency Assistance to Refugees. Oxford: Oxford University Press.

HelpAge Refugee Programme (Zimbabwe). 1992. An Application to the Overseas Development Assistance (ODA) Unit for Co-financing a Programme of Assistance to Elderly, Disabled Mozambican Refugees in Zimbabwe,
1 April 1992-31 March 1993. Harare: HelpAge.

Isaacman, A. and Barbara Isaacman. 1983. Mozambique: From Colonialism to Revolution, 1900-1982. Boulder, Colorado: Westview Press.

Keen, D. 1992. Refugees: Rationing the Right to Life. The Crisis in Emergency Relief. London: Zed Books.

Kibreab, G. 1987. Refugee and Development in Africa: The Case of Eritrea. Trenton, New Jersey: Red Sea Press.

Moussa, H. 1992. Storm and Sanctuary: The Journey of Ethiopian and Eritrean Women Refugees. Dundas, Ontario: Artemis Publishers.

Munyai, T. 1990. Elderly Women Refugees: Social Support Systems at Tongogara Refugee Camp. Unpublished B.A. (Social Work) thesis presented to the School of Social Work, Harare, Zimbabwe.

Popline. 1991. "Megacities Multiply in the Developing World." Popline (World New Service), 13 (July-August): 3.

Refugee Service of the Commission on InterChurch Aid, Refugee and World Service. 1987. Refugee Participation. Geneva: World Council of Churches.

Refugee Studies Programme (Oxford), School of Social Work (University of Zimbabwe), Chancellor College (University of Malawi). 1993. Aid, Non-governmental Agencies and Refugee Livelihood. Recommendations For The Way Forward. A Report for Governments and Agencies on Mozambican Refugees in Malawi and Zimbabwe. Oxford: Refugee Studies Programme.

Rogge, J. 1987. "When is Self-sufficiency Achieved?" in Refugees: A Third World Dilemma, edited by J.R. Rogge. New Jersey: Rowman and Littlefield.

-1990. Relocation and Repatriation of Displaced Persons in Sudan. A Report to the Minister of Relief and Displaced Persons' Affairs. Winnipeg: Disaster Research Unit, University of Manitoba.

Sen, G. and Caren Grown. 1985. Development, Crisis and Alternative Visions: Third World Women's Perspectives. New Delhi: Development Alternatives with Women for a New Era (DAWN).

United Nations High Commissioner for Refugees. 1991. Information Note on UNHCR Guidelines on the Protection of Refugee Women. Geneva: UNHCR.

Wiest, R.E., Jane S.P. Mocellin, and D. Thandiwe Motsisi. 1994. The Needs of Women in Disasters and Emergencies. A Report Prepared for the Disaster Management Training Institute of the UNDP, and the Office of the United Nations Disaster Relief Coordinator. Winnipeg: Disaster Research Unit, University of Manitoba.

Zimbabwe Government. 1983. Zimbabwe Refugee Act, No. 13 of 1983 . 